\title{
MINI-REVIEW
}

\section{Serological biomarkers of granuloma progression in sarcoidosis}

\author{
Chuyen Thi Hong Nguyen ${ }^{1,3^{*}}$, Naotomo Kambe ${ }^{1,2}$, \\ Ikuko Ueda-Hayakawa ${ }^{1}$, Hiroyuki Okamoto ${ }^{1}$ \\ ${ }^{1}$ Department of Dermatology, Kansai Medical University, Hirakata, Osaka, Japan \\ ${ }^{2}$ Allergy Center, Kansai Medical University, Hirakata, Osaka, Japan \\ ${ }^{3}$ Department of Dermatology and Venereology, University of Medicine and Pharmacy at Ho Chi Minh City, Vietnam
}

\begin{abstract}
Sarcoidosis is a systemic disorder with unknown etiology and pathogenesis characterized by non-caseating granulomas, and different clinical manifestations of sarcoidosis hinder diagnosis and treatment. Therefore, a comprehensive understanding of serological markers based on clinical observations of sarcoidosis and the progression of granulomas would aid analysis in routine clinical practice. In this review, we overview common serological markers, including angiotensin converting enzyme (ACE) and lysozyme, and describe in detail new promising indices in sarcoidosis such as a $\mathrm{T}$ cell serological marker (soluble interleukin 2 receptor; sIL-2R) and thymus and activationregulated chemokine (TARC/CCL17).
\end{abstract}

Keywords: serological biomarkers; angiotensin converting enzyme; lysozyme; soluble interleukin 2 receptor, granuloma; sarcoidosis

ARTICLE INFO

Received: February 21, 2020

Accepted: March 13, 2020

Available online: March 26, 2020

*CORRESPONDING AUTHOR

Chuyen Thi Hong Nguyen,

Department of Dermatology and

Venereology, University of Medicine and Pharmacy at Ho Chi Minh City,

Vietnam; chuyennguyen@ump.edu.vn

\section{CITATION}

Nguyen CTH, Kambe N, Ueda-

Hayakawa I, et al. Serological biomarkers of granuloma progression in sarcoidosis. Trends Immunother 2020; 4(1): 27-35.

doi: 10.24294/ti.v4.i1.721

\section{COPYRIGHT}

Copyright (C 2020 by author(s) and EnPress Publisher LLC. This work is licensed under the Creative Commons Attribution-NonCommercial 4.0 International License (CC BY-NC 4.0). http://creativecommons.org/licenses/ by/4.0/

\section{Introduction}

Sarcoidosis has striking clinical heterogeneity, but the etiology and pathogenesis of sarcoidosis are still poorly understood ${ }^{[1-4]}$. Various clinical manifestations ranging from no symptoms to severe outcomes, such as respiratory dysfunction, blindness, severe neurological disorders, and cardiac life-threatening conditions, may hinder diagnosis and treatment of sarcoidosis $^{[4]}$.

Diagnosing sarcoidosis is problematic because there is no definitive test ${ }^{[4]}$. Diagnosis is mainly based on a combination of clinical, radiological, and serological features, and supported by pathological findings ${ }^{[5]}$. Therefore, evidence of non-caseating granulomas from an easily accessed organ, such as a cutaneous tissue biopsy, facilitates diagnosis. The clinical utility of common serological markers is based on correlations with clinical manifestations, dynamics of the disease, and other severity indices such as pulmonary radiographical stage, the number of $\mathrm{CD}^{+} \mathrm{T}$ cells in bronchoalveolar lavage fluid (BALF), and the number of affected organs imaged by FDG ${ }^{18} \mathrm{PET}$ or ${ }^{67} \mathrm{Ga}$ scintigraphy ${ }^{[6]}$. However, there are no useful diagnostic, prognostic, or therapeutic serological markers that support the management of sarcoidosis in patients $^{[4]}$.

Sarcoidosis is a systemic disorder characterized by non-caseating granulomas. Granulomas are a collection of monocyte-macrophage lineage cells and lymphocytes, which surround but cannot eliminate various pathogens such as microorganisms, toxic molecules, or foreign bodies ${ }^{[7,8]}$. Granulomas containing pathogenic agents are "seeds" and are surrounded by epithelioid cells, mononuclear cells, and $\mathrm{T}$ cells on the periphery (Figure 1). These cells engulf or trap the pathogenic agents and prime the immune system by releasing pro-inflammatory cytokines ${ }^{[4]}$. The distribution of the cell population and intensity of the immune reaction may help shape acute or chronic disease 


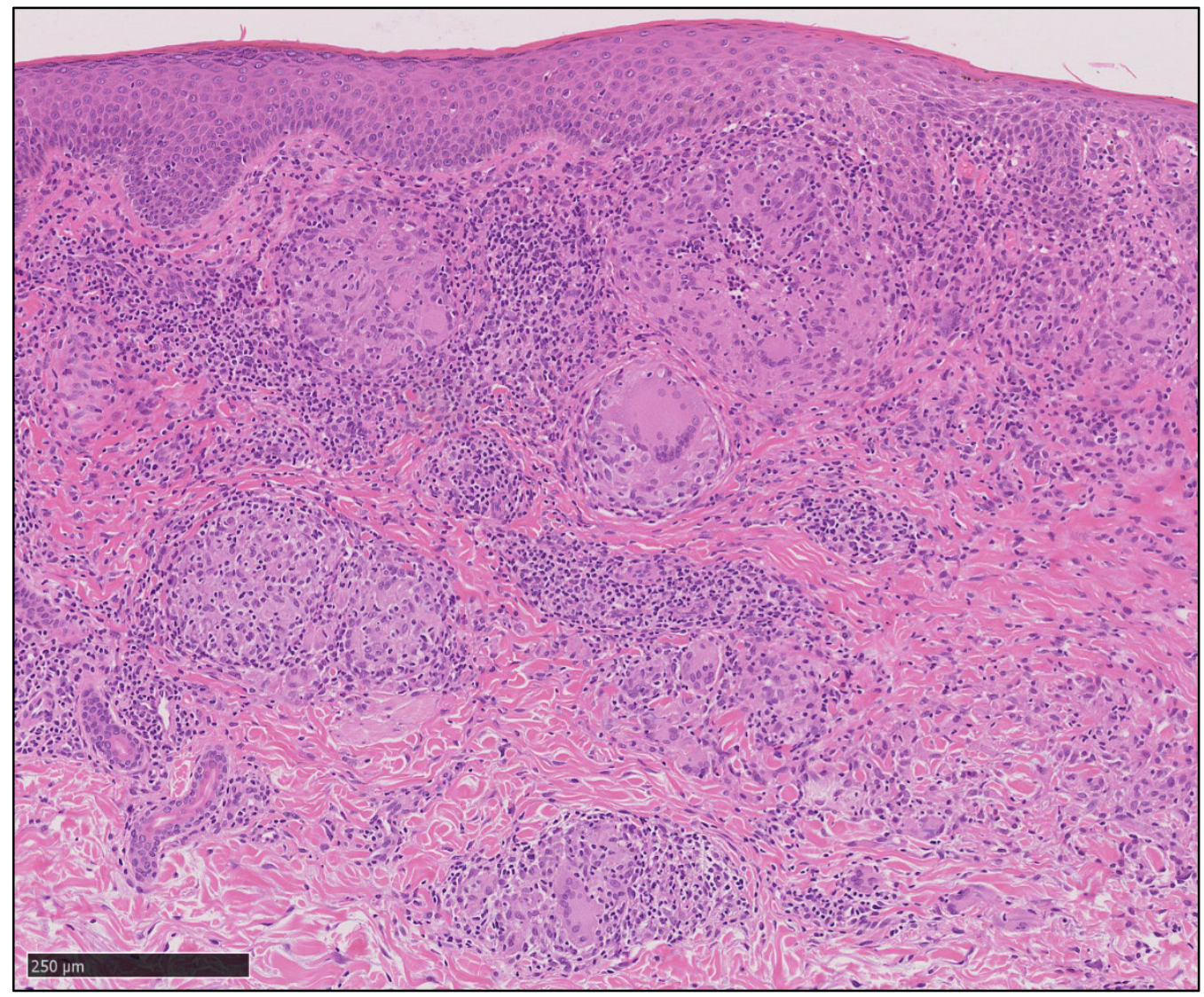

Figure 1. Network of cells in the formation of sarcoidal granuloma. A biopsied skin tissue with HE staining shows multiple non-caseating granulomas in the dermis. In sarcoidosis, a network of cells is responsible for building granulomas. The compact structure contains abundant epithelioid cells, multinucleated giant cells, and peripheral inflammatory cells, which are mainly T cells. Magnification is 20x.

$\operatorname{activity}^{[9]}$.

The origin of secreted serological markers during granulomatous inflammation may help track clinical progression of the disease. Here, we outline some common serological markers and focus on some promising $\mathrm{T}$ cell markers in sarcoidosis. In addition, we comprehensively describe the relationship between serological markers and the stages of sarcoidal granuloma formation, which may aid analysis of serological tests in routine clinical practice (Figure 2).

\section{Serological markers associated with granuloma}

At the "mature" stage of sarcoidal granuloma structure, there is a compact and organized collection of cells with abundant epithelioid cells at the center $^{[3]}$. These cells may fuse together and form multinucleated giant cells. Monocyte-macrophage lineage cells in the granuloma secrete ACE and lysozyme, which are commonly used "traditional" indices of total granuloma mass in sarcoidosis.
Epithelioid cells are the primary sources for ACE, and ACE is a measure of granuloma burden in sarcoidosis ${ }^{[3,10,11]}$. However, the role of ACE in the diagnosis of sarcoidosis is controversial because of low sensitivity and specificity ${ }^{[12]}$. The sensitivity of ACE levels for the diagnosis of sarcoidosis is $40-60 \%{ }^{[13-16]}$, but may be as low as $29 \%{ }^{[6]}$, which is similar to a study by Turton et al. ${ }^{[16]}$ Table 1 outlines the factors that contribute to the sensitivity and specificity of serum ACE. One factor that affects the sensitivity of ACE is an insertion (I)/delete (D) polymorphism in the ACE gene, which results in significantly different serum ACE levels between genotypes DD (high serum ACE), ID (intermediate serum ACE), and II (low serum ACE $)^{[17]}$. In addition, $\mathrm{ACE}$ is a secondary feature of sarcoidosis rather than an initial event of monocyte-macrophage lineage activity ${ }^{[18]}$. ACE is released by epithelioid cells, which are polarized by monocyte-macrophage lineage cells at the mature building stage of granuloma (Figure 2) ${ }^{[3]}$. Therefore, ACE may not be sensitive at an early stage and is probably not a good index of disease activity. Nevertheless, serum ACE 


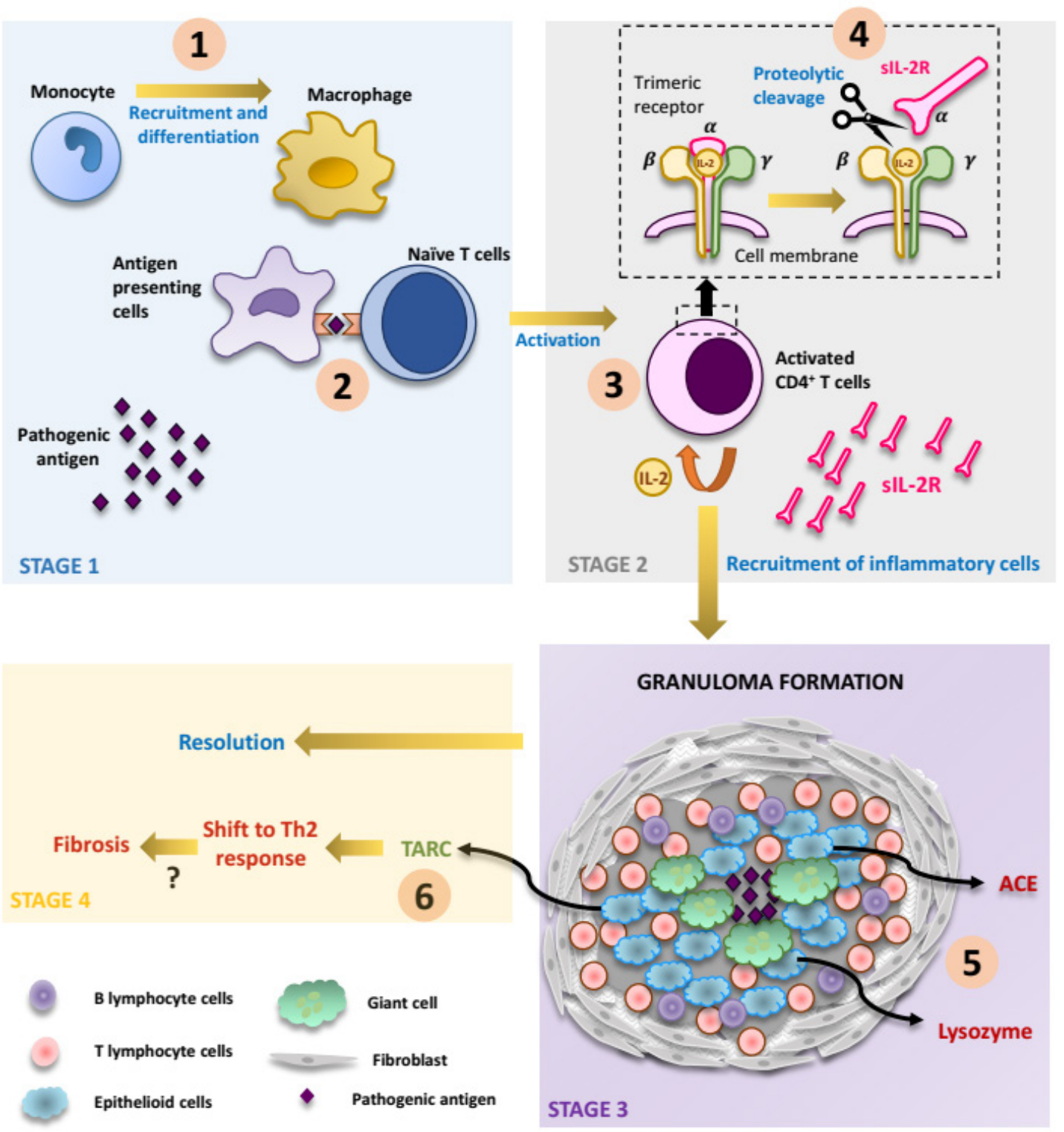

Figure 2. Serological markers during different stages of sarcoidal granuloma formation. Granuloma formation occurs in 4 stages including stage 1 (initial stage), stage 2 (accumulation of inflammatory cells), stage 3 (effector phase with the amplification of immune response to create a compact cell network to form granuloma), and stage 4 (resolution or fibrosis progression), and $\mathrm{T}$ helper cells are clearly involved in the mechanism of initiation, maintenance, and progressive fibrosis ${ }^{[3]}$. The main events that explain the expression of serological biomarkers during this progression are as follows:

(1) First, pathogenic antigens, including microorganism, toxic molecules, or foreign bodies ${ }^{[7,8]}$, activate the innate immune system and recruit peripheral monocytes, which then undergo differentiation into antigen-presenting cells.

(2) Antigen presentation activates naïve T cells.

(3) Activated T cells produce IL-2 as a local growth factor for T cells ${ }^{[5]}$ and express IL-2 receptor on their surface.

(4) Proteolytic cleavage of IL-2 $\alpha$ chain occurs after T cell stimulation ${ }^{[27]}$. The presence of the $\alpha$ chain in body fluids is a good measure of T-cell activation.

(5) Immune granulomas have a central follicle composed of a pathogenic antigen and epithelioid cells. These cells are the main source of ACE and lysozyme. T cells and B cells surround the "granuloma core" and are encircled by fibroblasts.

(6) TARC is mainly secreted by epithelioid cells and may drive the Th2 immune response in sarcoidosis. Shifting to a Th2 response may favor fibrotic progression and further investigation is needed to elucidate the underlying mechanism of this phenomenon. 
Table 1. Reasons for the poor sensitivity and specificity of serum ACE levels in the diagnosis of sarcoidosis.

\author{
1. Differences in test assays \\ 2. Differences in abnormal cut-off values \\ 3. Inconsistent diagnoses of sarcoidosis \\ 4. Measurement of serum ACE levels at different time points \\ 5. ACE may change after treatment ${ }^{[38]}$ \\ 6. Polymorphism of the ACE gene ${ }^{[17]}$
}

levels greater than two times the upper limit of the normal range can be used to support diagnosis and assessment of the clinical course of the disease ${ }^{[12,19]}$.

Lysozyme is a bacteriolytic enzyme produced by activated macrophages and epithelioid cells in the sarcoidal granuloma, but is not detected in regressing lesions ${ }^{[20]}$. Serum lysozyme levels increase in sarcoidosis, but its diagnostic value is poor ${ }^{[12,21]}$. About $70 \%$ of patients with sarcoidosis have a high level of serum lysozyme, but the sensitivity of lysozyme is only $26 \%$ in sarcoidosis patients with cutaneous lesions ${ }^{[16]}$. Lysozyme may be a marker of pulmonary lesions because it correlates with chest radiological stages and the number of total cells, lymphocytes, and $\mathrm{CD}^{+} \mathrm{T}$ cells in $\mathrm{BALF}^{[20]}$. Like ACE, lysozyme is secreted by epithelioid cells at the "mature" stages of granuloma (Figure 2). Thus, this serological marker may be a delayed reaction during the active phase of the disease and not sensitive to track the clinical course of progression or remission. However, it can be used to support diagnosis and follow-up of patients ${ }^{[21]}$.

\section{Serological markers associated with lymphocyte activation}

The hallmarks of sarcoidosis are non-caseating granulomas in which activated $T$ cells accumulate at inflammatory sites. Recruitment of peripheral $\mathrm{T}$ cells in blood to tissues amplifies inflammatory responses ${ }^{[2]}$. Sarcoidosis is an "immune paradox," in which the peripheral activity occurs with local exaggerated inflammation ${ }^{[1]}$.

Granuloma formation occurs in 4 stages: initial, accumulation, effector phase, and resolution or fibrosis progression, in which $\mathrm{T}$ helper cells are involved in the mechanism of initiation, maintenance, and progressive fibrosis (Figure $2^{[3,22,23]}$. In the stages of granuloma formation, T cell serological markers may help reveal the systemic inflammatory condition. Here, we discuss the links between clinical progression, dynamics of serological markers, and immunopathogenesis of sarcoidosis.

Interleukin-2 (IL-2) is a cytokine released predominantly by activated $\mathrm{CD} 4^{+} \mathrm{Th} 1$ cells and has an important role as a growth factor to amplify local immune responses ${ }^{[5]}$. Activated $\mathrm{T}$ cells express IL-2 receptors (IL-2R) consisting of 3 chains on their surfaces, and the $\alpha$ chain is proteolytically cleaved into the surrounding environment in a soluble form ${ }^{[24]}$. Soluble IL-2R induced by activated human lymphoid cells in vitro was first observed in 1985 , and two years later an increase in sIL-2R in the sera of sarcoidosis patients was reported ${ }^{[25,26]}$. These T cells produced IL-2 and express IL- $2 \alpha$ receptor on their surface only after being activated through antigen presentation. The intensity of $\mathrm{T}$ cell activation is high during the active disease, but low or absent in chronic sarcoidosis ${ }^{[9]}$. Therefore, the proteolytic cleavage of the soluble form of $\alpha$ chain from the cell surface into body fluids is a reliable measure of T-cell activation ${ }^{[27]}$. Several studies have found that sIL-2R is a clinically relevant marker of sarcoidosis to evaluate disease severity and treatment options (Table 2).

In 2015, sIL-2R replaced the negative tuberculin test for diagnosis sarcoidosis in Japan (Table 3) ${ }^{[28]}$, and a 2017 study found that sIL-2R was more sensitive than ACE or lysozyme for diagnosing patients with cutaneous lesions ${ }^{[6]}$. About $30 \%$ of patients had increased serum sIL-2R levels but normal serum ACE levels, and 19\% of patients had elevated serum sIL-2R levels but normal lysozyme levels on their first visit. During follow-up, sIL-2R levels also correlated with clinical progress, but $\mathrm{ACE}$ and lysozyme levels were not correlated ${ }^{[6,20,29]}$.

sIL-2R is released by activated T cells, which are recruited at an early phase of granuloma formation and increase during active disease, and sIL-2R is also secreted by activated monocytes, $\mathrm{B}$ cells, and alveolar macrophages in sarcoidosis ${ }^{[30]}$. Therefore, an increased level of serum sIL-2R is a reliable index of ongoing systemic granulomatous inflammation and has higher sensitivity compared to ACE or lysozyme for diagnosing sarcoidosis. In addition, activated $\mathrm{T}$ cells target the affected area and proliferate during the initial immune response in the formation of the granuloma, which suggests that sIL-2R is an early marker of active sarcoidosis. Unfortunately, sIL$2 \mathrm{R}$ is non-specific because it increases in other conditions $^{[31]}$, but may still be used to identify sarcoidosis in suspected patients with a noncaseating necrosis granuloma in a cutaneous biopsy. 


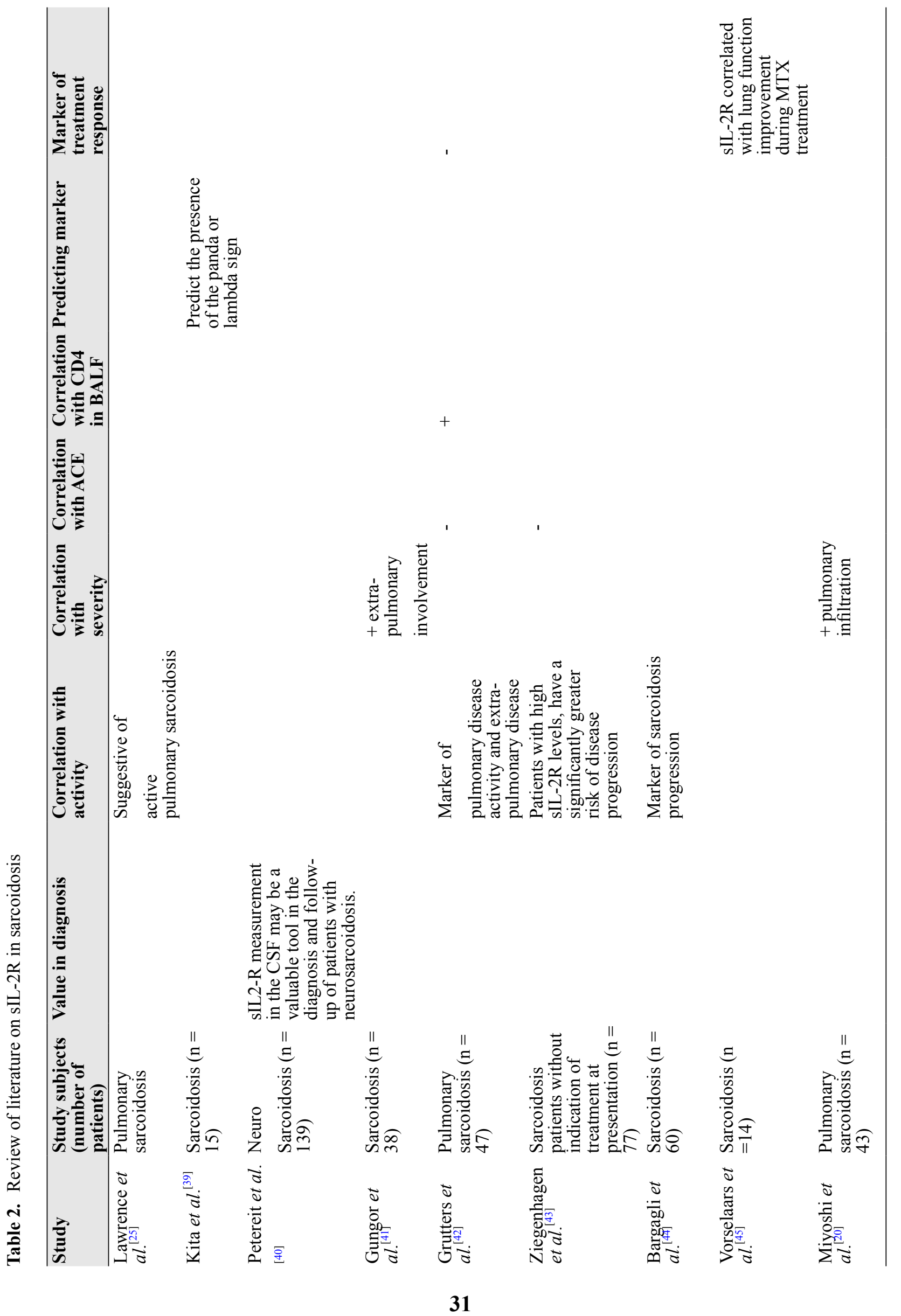




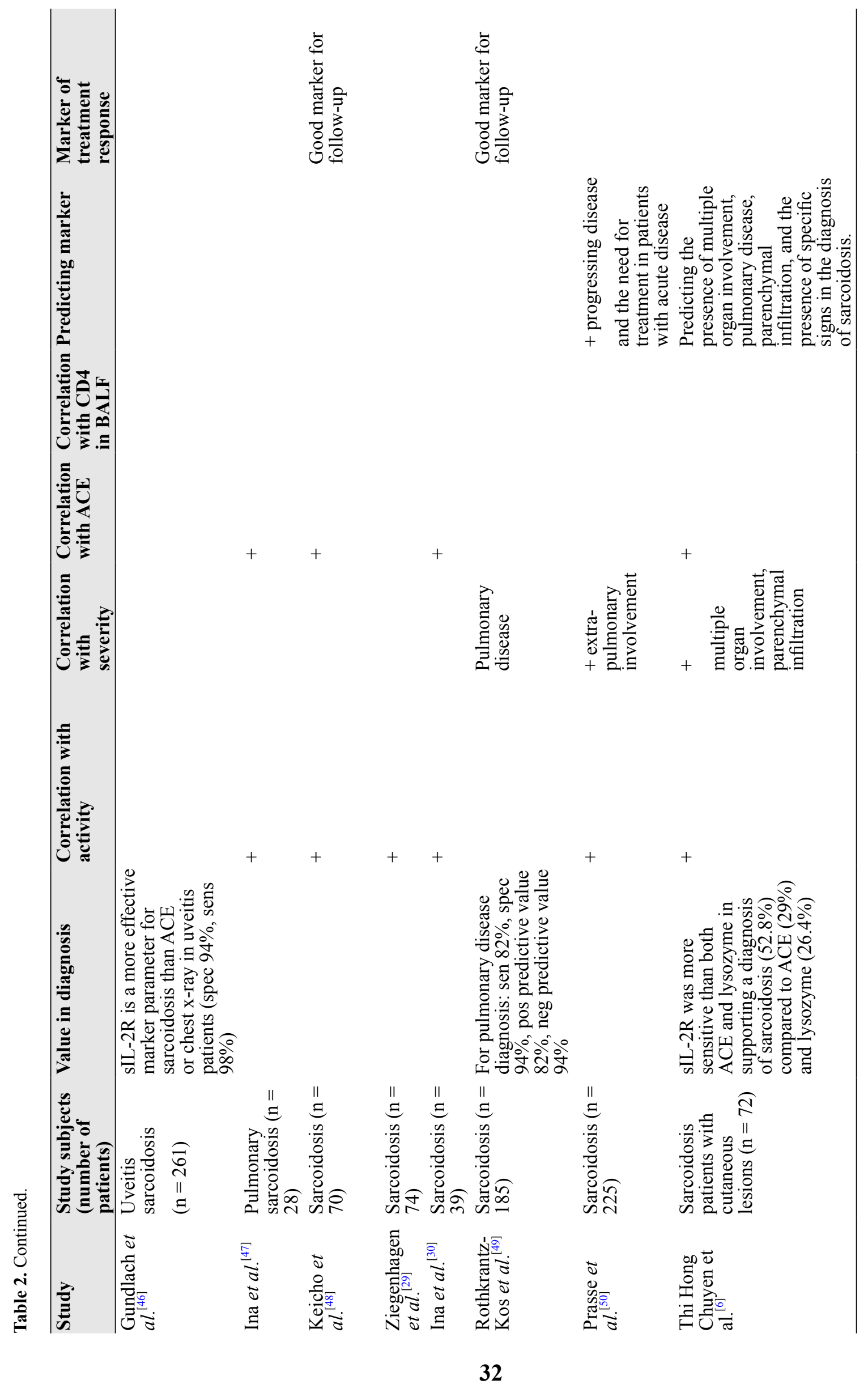


Table 3. Diagnostic criteria for sarcoidosis in $\operatorname{Japan}^{[28]}$

\section{(A) Definitive Diagnosis (Clinical and histological evidence group)}

More than one clinical sarcoidal lesion with non-caseating necrosis epithelioid cell granulomas, and rule-out other granulomatous disorders and sarcoid reactions.

Note: Careful examination of characteristic laboratory findings for sarcoidosis and systemic involvement is necessary.

\section{(B) Possible Diagnosis (Absence of histological evidence group)}

Two of three important organ involvements (lung, eye, and heart) and two of five characteristic laboratory findings are needed for diagnosis.

1. BHL

2. High serum levels of ACE or lysozyme

3. High serum level of sIL-2R

4. Abnormal accumulation in ${ }^{67} \mathrm{Ga}$ scintigraphy or PET-CT

5. An increased number of lymphocytes or a CD4/CD8 ratio more than 3.5 in BALF

\section{Serological markers associated with fibrotic remodeling}

$\mathrm{T}$ helper type 1 (Th1) responses and Th1associated cytokines are key players in the pathogenesis of sarcoidosis, but the mechanism of granuloma formation and fibrosis is unknown. Th1 and Th2 cytokine expression patterns in sarcoidosis are important to predict the clinical outcome of an immune response, in which a Th1 response results in an antigen/pathogen clearance and resolution and a $\mathrm{Th} 2$ response results in fibrosis remodeling ${ }^{[22]}$.

TARC, also known as chemokine ( $\mathrm{C}-\mathrm{C}$ motif) ligand 17 (CCL17), is a crucial chemokine for the amplification of Th2 responses, which occur by recruiting CCR4-expressing $\mathrm{CD}^{+}{ }^{+} \mathrm{T}$ cells.[32-35] Increased serum levels of TARC are implicated in non-specific compensate reactions in the Th1 response in sarcoidosis ${ }^{[36]}$. Serum TARC levels are elevated in $78 \%$ of sarcoidosis patients and expressed by monocyte-macrophage lineage cells within granulomas. In addition, an imbalance between Th1 and Th2 results in a Th2 response that underlies prolonged TARC overproduction. Therefore, TARC is actively involved in the pathogenesis of sarcoidosis. One third of patients with sarcoidosis may have a chronic disease with a high risk of fibrosis. Patients with increased serum TARC levels have a significantly increased incidence of pulmonary infiltration. In the clinical practice, TARC may be good predictive marker for pulmonary fibrotic progression in chronic sarcoidosis patients ${ }^{[37]}$. Understanding the role of TARC in promoting and maintaining local and systemic inflammatory reactions is important because it may lead to targeted treatments to prevent fibrosis events.

\section{Conclusion}

Based on the progression of sarcoidal granuloma, sIL-2R is a more useful marker than other indicators in an early and active condition, and "traditional" indices, such as ACE and lysozyme, are less sensitive for the diagnosis and management of sarcoidosis. TARC is a promising marker, but further investigation on Th2 activity in sarcoidosis and fibrosis mechanisms is needed. Understanding the link between clinical observations and serological markers in sarcoidosis may aid clinicians treating this challenging disease.

\section{Conflict of interest}

The authors declare no potential conflicts of interest.

\section{References}

1. Loke WS, Herbert C, Thomas PS. Sarcoidosis: Immunopathogenesis and Immunological Markers. Int J Chronic Dis 2013; 2013: 928601. doi: 10.1155/2013/928601.

2. English JC, 3rd, Patel PJ, Greer KE. Sarcoidosis. J Am Acad Dermatol 2001; 44(5): 725-743; quiz 744-726. doi: 10.1067/mjd.2001.114596.

3. Iannuzzi MC, Fontana JR. Sarcoidosis: Clinical presentation, immunopathogenesis, and therapeutics. Jama 2011; 305(4): 391-399. doi: 10.1001/ jama.2011.10.

4. Chen ES, Moller DR. Sarcoidosis: Scientific progress and clinical challenges. Nat Rev Rheumatol 2011; 7(8): 457-467. doi: 10.1038/nrrheum.2011.93. 
5. Iannuzzi MC, Rybicki BA, Teirstein AS. Sarcoidosis. The New England journal of medicine 2007; 357(21): 2153-2165. doi: 10.1056/NEJMra071714.

6. Thi Hong Nguyen C, Kambe N, Kishimoto I, et al. Serum soluble interleukin-2 receptor level is more sensitive than angiotensin-converting enzyme or lysozyme for diagnosis of sarcoidosis and may be a marker of multiple organ involvement. J Dermatol 2017. doi: 10.1111/1346-8138.13792.

7. Zumla A, James DG. Granulomatous infections: Etiology and classification. Clin Infect Dis 1996; 23(1): 146-158. doi: 10.1093/clinids/23.1.146.

8. Molina-Ruiz AM, Requena L. Foreign Body Granulomas. Dermatol Clin 2015; 33(3): 497-523. doi: 10.1016/j.det.2015.03.014.

9. Zissel G, Muller-Quernheim J. Cellular Players in the Immunopathogenesis of Sarcoidosis. Clinics in chest medicine 2015; 36(4): 549-560. doi: 10.1016/ j.ccm.2015.08.016.

10. Lynch JP, 3rd, Kazerooni EA, Gay SE. Pulmonary sarcoidosis. Clinics in chest medicine 1997; 18(4): 755-785. doi: 10.1016/j.ccm.2004.04.006.

11. Gilbert S, Steinbrech DS, Landas SK, et al. Amounts of angiotensin-converting enzyme mRNA reflect the burden of granulomas in granulomatous lung disease. The American review of respiratory disease 1993; 148(2): 483-486. doi: 10.1164/ajrccm/148.2.483.

12. Chopra A, Kalkanis A, Judson MA. Biomarkers in sarcoidosis. Expert Rev Clin Immunol 2016; 12(11): 1191-1208. doi: 10.1080/1744666x.2016.1196135.

13. DeRemee RA, Rohrbach MS. Serum angiotensinconverting enzyme activity in evaluating the clinical course of sarcoidosis. Annals of internal medicine 1980; 92(3): 361-365. doi: 10.7326/0003-4819-92-3361.

14. Gronhagen-Riska C, Selroos O, Wagar G, et al. Angiotensin-converting enzyme. II. Serum activity in early and newly diagnosed sarcoidosis. Scandinavian J Respir Dis 1979; 60(2): 94-101.

15. Lieberman J. Elevation of serum angiotensinconverting-enzyme (ACE) level in sarcoidosis. Am J Med 1975; 59(3): 365-372. doi: 10.1016/00029343(75)90395-2.

16. Turton CW, Grundy E, Firth G, et al. Value of measuring serum angiotensin I converting enzyme and serum lysozyme in the management of sarcoidosis. Thorax 1979; 34(1): 57-62. doi: 10.1136/ thx.34.1.57.

17. Tomita H, Ina Y, Sugiura Y, et al. Polymorphism in the angiotensin-converting enzyme (ACE) gene and sarcoidosis. Am J Respir Crit Care Med 1997; 156(1): 255-259. doi: 10.1164/ajrccm.156.1.9612011.

18. Gronhagen-Riska C, Selroos O. Angiotensin converting enzyme. IV. Changes in serum activity and in lysozyme concentrations as indicators of the course of untreated sarcoidosis. Scandinavian J Respir Dis 1979; 60(6): 337-344.

19. Lieberman J, Nosal A, Schlessner A, et al. Serum angiotensin-converting enzyme for diagnosis and therapeutic evaluation of sarcoidosis. The American review of respiratory disease $1979 ; 120(2)$ : 329-335. doi: 10.1164/arrd.1979.120.2.329.

20. Miyoshi S, Hamada $\mathrm{H}$, Kadowaki $\mathrm{T}$, et al. Comparative evaluation of serum markers in pulmonary sarcoidosis. Chest 2010; 137(6): 13911397. doi: 10.1378/chest.09-1975.

21. Tomita H, Sato S, Matsuda R, et al. Serum lysozyme levels and clinical features of sarcoidosis. Lung 1999; 177(3): 161-167. doi: 10.1007/PL00007637.

22. Nicholas W. Lukacs CH, Stephan W. Chensue, Kate Blease, et al. Type1/Type2 Cytokine Paradigm and the Progression of pulmonary fibrosis. Chest 2001; 120(1 Suppl): 5S-8S. doi: 10.1378/chest.120.1 suppl.S5.

23. Ben G. Marshall RJS. T Cells and Fibrosis. Chemical immunology 2000; 78: 148-158. doi: 10.1159/000058824.

24. Boyman O, Sprent J. The role of interleukin-2 during homeostasis and activation of the immune system. Nat Rev Immunol 2012; 12(3): 180-190. doi: 10.1038/nri3156.

25. Lawrence EC, Berger MB, Brousseau KP, et al. Elevated serum levels of soluble interleukin-2 receptors in active pulmonary sarcoidosis: Relative specificity and association with hypercalcemia. Sarcoidosis 1987; 4(2): 87-93.

26. Rubin LA, Kurman CC, Fritz ME, et al. Soluble interleukin 2 receptors are released from activated human lymphoid cells in vitro. J Immunol (Baltimore, Md : 1950) 1985; 135(5): 3172-3177.

27. Witkowska AM. On the role of sIL-2R measurements in rheumatoid arthritis and cancers. Mediators of inflammation 2005; 2005(3): 121-130. doi: 10.1155/ mi.2005.121.

28. Shijubo N, TY. Diagnosis Criteria and Classification of Disease Severity for Sarcoidosis in Japan. The Japanese journal of Sarcoidosis and Other Granulomatous Disorders 2015; 35(1): 3-8.

29. Ziegenhagen MW, Rothe ME, Schlaak M, et al. Bronchoalveolar and serological parameters reflecting the severity of sarcoidosis. Eur Respir J 2003; 21(3): 407-413. doi: 10.1183/09031936.03.00010403.

30. Ina Y, Takada K, Sato T, et al. Soluble interleukin 2 receptors in patients with sarcoidosis. Possible origin. Chest 1992; 102(4): 1128-1133. doi: 10.1378/ chest.102.4.1128.

31. Rubin LA, Nelson DL. The soluble interleukin-2 receptor: Biology, function, and clinical application. Annals of internal medicine 1990; 113(8): 619-627. doi: 10.7326/0003-4819-113-8-619.

32. Imai T, Yoshida T, Baba M, et al. Molecular cloning of a novel T cell-directed CC chemokine expressed in thymus by signal sequence trap using EpsteinBarr virus vector. J Bio chem 1996; 271(35): 21514 21521.

33. Imai T, Baba M, Nishimura $\mathrm{M}$, et al. The T celldirected CC chemokine TARC is a highly specific biological ligand for $\mathrm{CC}$ chemokine receptor 4 . J Bio chem 1997; 272(23): 15036-15042.

34. Sallusto F, Lanzavecchia A, Mackay CR. Chemokines and chemokine receptors in T-cell priming and Th1/ Th2-mediated responses. Immunology today 1998; 
19(12): 568-574.

35. D'Ambrosio D, Iellem A, Bonecchi R, et al. Selective up-regulation of chemokine receptors CCR4 and CCR8 upon activation of polarized human type 2 Th cells. J Immunol (Baltimore, Md : 1950) 1998; 161(10): 5111-5115.

36. Nureki S, Miyazaki E, Ando M, et al. Circulating levels of both Th1 and Th2 chemokines are elevated in patients with sarcoidosis. Respiratory medicine 2008; 102(2): 239-247. doi: 10.1016/ j.rmed.2007.09.006.

37. Nguyen CTH, Kambe N, Ueda-Hayakawa I, et al. TARC expression in the circulation and cutaneous granulomas correlates with disease severity and indicates Th2-mediated progression in patients with sarcoidosis. Allergol Int 2018; S1323-8930(18)300169. doi: 10.1016/j.alit.2018.02.011.

38. Baughman RP, Ploysongsang Y, Roberts RD, et al. Effects of sarcoid and steroids on angiotensinconverting enzyme. The American review of respiratory disease 1983 ; 128(4): 631-633. doi: 10.1164/arrd.1983.128.4.631.

39. Kita $\mathrm{T}$, Watanabe S, Yano $\mathrm{F}$, et al. Clinical significance of the serum IL-2R level and Ga-67 scan findings in making a differential diagnosis between sarcoidosis and non-Hodgkin's lymphoma. Ann Nucl Med 2007; 21(9): 499-503. doi: 10.1007/s12149007-0060-9.

40. Petereit HF, Reske D, Tumani H, et al. Soluble CSF interleukin 2 receptor as indicator of neurosarcoidosis. J Neurol 2010; 257(11): 1855-1863. doi: 10.1007/ s00415-010-5623-3.

41. Gungor S, Ozseker F, Yalcinsoy M, et al. Conventional markers in determination of activity of sarcoidosis. International immunopharmacology 2015; 25(1): 174 179. doi: 10.1016/j.intimp.2015.01.015.

42. Grutters JC, Fellrath JM, Mulder L, et al. Serum soluble interleukin-2 receptor measurement in patients with sarcoidosis: A clinical evaluation. Chest 2003; 124(1): 186-195. doi: 10.1378/chest.124.1.186.
43. Ziegenhagen MW, Benner UK, Zissel G, et al. Sarcoidosis: TNF-alpha release from alveolar macrophages and serum level of sIL-2R are prognostic markers. Am J Respir Crit Care Med 1997; 156(5): 1586-1592. doi: 10.1164/ ajrccm.156.5.97-02050.

44. Bargagli E, Bianchi N, Margollicci $\mathrm{M}$, et al. Chitotriosidase and soluble IL-2 receptor: Comparison of two markers of sarcoidosis severity. Scand J Clin Lab Invest 2008; 68(6): 479-483. doi: $10.1080 / 00365510701854975$.

45. Vorselaars AD, van Moorsel CH, Zanen P, et al. ACE and sIL-2R correlate with lung function improvement in sarcoidosis during methotrexate therapy. Respiratory medicine 2015; 109(2): 279-285. doi: 10.1016/j.rmed.2014.11.009.

46. Gundlach E, Hoffmann MM, Prasse A, et al. Interleukin-2 Receptor and Angiotensin-Converting Enzyme as Markers for Ocular Sarcoidosis. PloS one 2016; 11(1): e0147258. doi: 10.1371/journal. pone. 0147258 .

47. Ina Y, Takada $\mathrm{K}$, Noda M, et al. Serum soluble IL-2 receptor level in patients with sarcoidosis. Nihon Kyobu Shikkan Gakkai Zasshi 1991; 29(3): 316-321. doi; 10.11389/jjrs1963.29.316.

48. Keicho N, Kitamura K, Takaku F, et al. Serum concentration of soluble interleukin-2 receptor as a sensitive parameter of disease activity in sarcoidosis. Chest 1990; 98(5): 1125-1129.

49. Rothkrantz-Kos S, van Dieijen-Visser MP, Mulder PG, et al. Potential usefulness of inflammatory markers to monitor respiratory functional impairment in sarcoidosis. Clinical chemistry 2003; 49(9): 1510 1517.

50. Prasse A, Katic C, Germann M, et al. Phenotyping sarcoidosis from a pulmonary perspective. Am J Respir Crit Care Med 2008; 177(3): 330-336. doi: 10.1164/rccm.200705-742OC. 